Research Square
Preprints are preliminary reports that have not undergone peer review.

They should not be considered conclusive, used to inform clinical practice, or referenced by the media as validated information.

\title{
Distribution of blaOXA, blaSHV, and blaTEM type extended-spectrum $\beta$-lactamase genes in multi-drug resistant Gram-negative isolates from burn patients of Lahore, Pakistan
}

\author{
Muhammad Hayat Haider \\ University of the Punjab \\ Noor Ul Ain \\ University of the Punjab \\ Samyyia Abrar \\ University of the Punjab \\ Saba Riaz ( $\square$ saba.mmg@pu.edu.pk) \\ University of the Punjab
}

\section{Research}

Keywords: Burn infections, Multidrug resistant isolates, Cephalosporins resistant isolates, Genotypic variants, Pseudomonas spp,

Enterobacteriaceae

Posted Date: December 16th, 2019

DOI: https://doi.org/10.21203/rs.2.18732/v1

License: @ (1) This work is licensed under a Creative Commons Attribution 4.0 International License. Read Full License 


\section{Abstract}

Background Multidrug resistant Gram-negative bacterial pathogens are becoming a lethal source of infections and associated complications of sepsis and multiple organ failure following burn injuries. Genotypic variants of bla OXA , bla SHV and bla TEM type extended-spectrum- $\beta$-lactamases (ESBLs) have been detected in Pseudomonas aeruginosa, Enterobacteriaceae and other type of bacteria. These hydrolytic enzymes are responsible for the degradation of broad-spectrum antimicrobials including third generation cephalosporins. We aimed to determine the distribution of ESBLs gene variants among MDR pathogens from post burn infections.

Methods A total of 358 specimens were collected during the period from 15 th August 2017 to 15 th August 2018 from burnt patients at Jinnah Burn and Reconstructive Surgery Centre (JB\&RSC).

Results $53.57 \%$ cephalosporins resistant isolates were found to be associated with a slightly higher frequency of $50.7 \%$ community-acquired and $49.30 \%$ nosocomial infections. $72 \%$ of these infections was found to be associated with males ( $p$-value $=0.919,0 R=1.038$ ). The age of burn victims ranged from 4 to 85 years (Mean=28.95, $S D= \pm 15.65$ ). Pseudomonas spp., were the predominant as $49.33 \%$ followed by $22.67 \%$ Klebsiella spp., $20 \%$ Acinetobacter spp., and 8\% Proteus spp., strains. There were $83.33 \%$ multidrug resistant isolates and meropenem, imipenem, and amikacin were found to be effective against $28.70 \%, 25.30 \%$, and $26.00 \%$ of cephalosporins resistant strains respectively. Lowest sensitivity of phenotypic tests was observed as 16\% ESBLs were detected by double disk synergism test (DDST) and $14 \%$ were confirmed by combination disk test (CDT). Molecular detection proved to be effective for the detection of $79.71 \%$ bla TEM , $37.68 \%$ bla OXA , and $18.84 \%$ bla SHV isolates. bla TEM genes were confirmed in $18.18 \%$ CDT positive isolates with $62.67 \%$ diagnostic accuracy $(95 \% \mathrm{Cl}=54.70,70.00)$ and $88.42 \%$ specificity $(95 \% \mathrm{Cl}=80.45,93.41)$. All of the bla TEM positive isolates were resistant to cefuroxime and $98.18 \%$ were resistant to cephradine, and piperacillin.

Conclusion The antimicrobial resistance associated with the ESBLs producing Pseudomonas spp., and Enterobacteriaceae is becoming a challenge for the treatment and survival of burn patients. The higher frequency of MDR isolates and detection of bla TEM, bla OXA, and bla SHV genes confirms that management of burn patients should be improved to prevent the infections.

\section{Introduction}

Burn incidents are frequently reported from low and middle income countries(1). According to WHO report of 2012, worldwide 195000 are caused by burns(2). WHO also reported 7.1 million fire incidents in 2004 and the incidence rate was 110/10000 cases worldwide. Southeast Asia and Middle-East regions were found to be more affected with 243/10000 and 187/10000 incidence respectively, as compared to lowest incidence of 19/10000 in the United States of America(3). Post-burn infections pose a global threat as a major public health problem(4). Nosocomial infections are predominant in burn patients and $75 \%$ of deaths occur within a few days of burn exposure due to sepsis and severity of infection (5).

Multidrug resistant Gram-negative bacterial strains are rapidly emerging as etiological agents in $50 \%$ of post-burn infections (6). Sepsis is the ultimate consequence of infections caused by bacterial invasion of traumatized skin (7). Both the Gram-negative and positive bacterial strains are reported to be associated with the post burn infections including Pseudomonas spp., Acinetobacter spp., Enterobacteriaceae, Staphylococcus spp., and Streptococcuspyogenes(8). Pseudomonasaeruginosa is the predominant bacterial pathogen among clinical isolates of burnt patients (9).

Multidrug resistance in Gram-negative isolates is found to be associated with the acquisition of $\beta$-lactamase gene variants (10). $\beta$ lactamases are either encoded in the plasmids or chromosomal DNA (11). ESBLs are known for hydrolyzing the penicillins, third and fourth generation cephalosporins and monobactams (12). Ambler classification involves four classes of $\beta$-lactamases including class A, B, C, and $D$ (13). Class A ESBLs such as sulfhydryl variant (SHV) and TemorinaEscherichia coli mutant (TEM) are inactivated by $\beta$-lactamase inhibitors including clavulanic acid, sulbactam, tazobactam (14).

Particular types of ESBLs are also capable of inactivating the aminoglycosides and sulphonamides (15). Class D oxacillinases (OXA type ESBLs) including bla $_{\mathrm{OXA}-10}$ and bla $\mathrm{OXA}_{48}$ are capable of degrading the cephalosporins and carbapenems respectively (16). Cephamycins and carbapenems are resistant to degradation by ESBLs (13).

To date, 193 variants of bla $\mathrm{SHV}_{\mathrm{SH}}$ and 223 variants of $\mathrm{bla}_{\mathrm{TEM}}$ have been reported worldwide (12). SHV enzymes are commonly found in Enterobacteriaceae including Klebsiella spp., and E. coli but other species also produce them includingP. aeruginosa and Acinetobacterbaumannii(17). bla $\mathrm{SHV}_{5}$ and bla $\mathrm{SHV} 12_{2}$ from Korea and Japan, bla $\mathrm{TEM} 12_{2}$ and bla $\mathrm{TEM} 52_{2}$ from the United Kingdom, bla $\mathrm{OXA10}_{10}$ and bla $_{\text {OXA13 }}$ have been reported from Iran and France respectively (18). A recent study from Pakistan revealed $40 \%$ of ESBLs producing bacteria in burn isolates (19). Horizontal transfer by plasmids and transposons during conjugation is a principal genetic factor for worldwide 
dissemination of ESBLs encoding genes (20). Self-medication is a contributing factor behind rapidly developing antimicrobial resistance (21). Rapid and accurate diagnosis of infectious agents is necessary for appropriate antibiotic prescription (22). The main objective of this study was to determine the frequency distribution of MDR bacterial pathogens implicated in post-burn infections. Secondly, we aimed to determine the frequency of the most prevalent types of genetic variants of bla $\mathrm{OXA}_{\mathrm{A}}, \mathrm{bla}_{\mathrm{SHV}}$, and bla $\mathrm{TEM}_{\mathrm{TESBLs}}$ encoding genes that might be associated with the dissemination of antimicrobial resistance in the community acquired and nosocomial pathogens. The molecular detection of ESBLs by multiplex PCR was employed in order to test the validatetheir use as a routine diagnostic procedure which would reduce the cost and duration of the treatment.

\section{Methods}

\section{Study design and clinical setting}

A cross-sectional study was conducted at Jinnah Burn and Reconstructive Surgery Centre (JB\&RSC) and the Department of Microbiology and Molecular Genetics, University of the Punjab Lahore. Ethical approval was obtained from Jinnah Hospital Lahore on $40^{\text {th }}$ meeting of the Ethical Review Board on $12^{\text {th }}$ August 2017. The bacteriological profiling, antimicrobial susceptibility testing (AST), and genotypic screening were performed during the period from $15^{\text {th }}$ August 2017 to $15^{\text {th }}$ August 2018. Both pediatric and adult patients were included for the analysis if they had clinical signs and symptoms such as pain, swelling of burn wounds and infection. The cephalosporins and carbapenems resistant Gram-negative isolates were further processed for the phenotypic identification and genetic profiling of ESBLs by $b / a_{\mathrm{OXA}}, b / a_{\mathrm{SHV}}$, and $b / a_{\mathrm{TEM}}$ multiplex PCR. Burnt patients suffering from previous infections, those receiving antibiotic therapy, and cephalosporins sensitive Gram-negative and positive isolates were excluded.

\section{Bacteriological profiling and data collection}

A total of 358 samples including wounds swabs, blood and tissue biopsy specimens were collected from the patients under treatment in burn unit's OPD, general ward, intensive care unit (ICU), and plastic surgery ward. Gram-positive isolates were excluded from further analysis.Antimicrobial susceptibility testing was performed after identification of bacterial isolates.

\section{Antimicrobial susceptibility testing and phenotypic detection of ESBLS}

The antimicrobial resistance and susceptibility patterns were analyzed by performing Kirby Bauer's disk diffusion method according to Clinical Laboratory Standards Institute (CLSI) 2017 guidelines $^{23}$. Bioanalyse ${ }^{\circledR}$ (Turkey) antimicrobial discs were used for AST profiling of Gram-negative bacterial isolates.Preliminary ESBLs detection was performed by double disk synergism test (DDST) and confirmatory combination disk test (CDT) (24).

\section{$b / a_{\mathrm{OXA}}, b / a_{\mathrm{SHV}}$, and $b / a_{\mathrm{TEM}}$ multiplex PCR}

Whole-genomic DNA extraction was performed by the boiling lysis method by preparing the cells suspension of purely isolated bacterial colonies as described previously (25). Previously designed conserved regions specific bla $a_{\mathrm{OXA}}, b / a_{\mathrm{SHV}}$, and bla $a_{\mathrm{TEM}}$ primers were optimized for multiplex PCR $(26,27)$. PCR amplicons were visualized by agarose-gel electrophoresis with $1 \%$ agarose gel and $1 X$ Tris-borate-EDTA (TBE) buffer.

\section{Statistical analysis}

Statistical Package for Social Sciences (SPSS) version 23 has been used for the execution of all statistical analyses. The association of ESBLs genotypes with the antimicrobial resistance has been demonstrated by percentages. The p-value of $<0.05$ has been taken as significant in the frequency distribution of infections among males and females and validity testing of ESBLs genes detection.

\section{Results}

\section{Distribution of clinical isolates}

During one year, $\mathrm{n}=358$ specimens were collected from burns patients admitted in Jinnah Burn and Reconstructive Surgery Centre (JB\&RSC) Lahore. Among $n=280(78.21 \%)$ positive cultures, $n=150(53.57 \%)$ cephalosporins resistant isolates were further processed for the detection of ESBLs by phenotypic tests and multiplex PCR. Age of the patients ranged from minimum of 4 years to maximum of 85 years (Mean=28.95, $\mathrm{SD}= \pm 15.65)$. 
The majority of cases $n=106(70.67 \%)$ were reported as inpatients and $n=44(29.33 \%)$ as outdoor patients. Pseudomonas spp., was the most commonly isolated pathogen in $\mathrm{n}=74(49.33 \%)$ patients while Klebsiella spp., infected 34(22.67\%) patients. Acinetobacter spp., and Proteus spp., were isolated from $n=30(20.00 \%)$, and $n=12(8.00 \%)$ patients respectively.

\section{Antimicrobial susceptibility testing and phenotypic detection of ESBLs}

Meropenem and imipenem proved to be effective only against $43(28.70 \%)$ and $38(25.30 \%)$ isolates respectively. Cefoperazone amongst cephalosporins demonstrated sensitivity against 22(14.70\%) strains followed by cefotaxime 14(9.30\%) and ceftazidime 14(9.30\%). Amikacin was the most effective aminoglycoside with $39(26.00 \%)$ of isolates being sensitive. Aztreonam and tigecycline exhibited the intermediate sensitivity patterns in $36(24.00 \%)$ and $21(14.00 \%)$ isolates. Polymyxin E with $83(55.30 \%)$ sensitivity proved to bethe most effective therapeutic agent for post-burn infections. There were 125(83.33\%) cephalosporins resistant MDR isolates with resistance against more than two or three antimicrobial agents. These multidrug resistant strains were also resistant to nalidixic acid and tetracycline (Table1).There were $24(16.00 \%)$ ESBLs producing cephalosporins resistant isolates detected by double disk synergism test (DDST) of which 21(14.00\%) were also detected by confirmatory combination disk test (CDT). Pseudomonasspp., was the predominant ESBLs producer as $10(13.51 \%)$ strains were confirmed by CDT as ESBLs producers. Klebsiella spp., Acinetobacter spp., and Proteus spp., strains were relatively low in number with 5(14.71\%), 4(13.33\%), and 2(16.67\%) as ESBLs producers respectively. A large number of these cephalosporins resistant isolates were not-determined phenotypically as ESBLs producers.

\section{Detection of $b / a_{O X A}, b / a_{S H V}$, and $b / a_{T E M}$ type ESBLs genes}

All of the cephalosporins resistant strains were screened by PCR for the detection of ESBLs encoding genes. There were 69(46.00\%) isolates found to be positive for ESBLs genes as detected by PCR. ESBLs genes were detected in 29(39.19\%) Pseudomonas spp., 23(67.64\%) Klebsiella spp., 13(43.33\%) Acinetobacter spp., and 4(33.33\%) Proteus spp., strains. Multiplex PCR confirmed co-existence of bla ${ }_{\text {TEM }}$ and bla $a_{\mathrm{SHV}}$ genes in $12(17.39 \%)$ patients. bla $a_{\mathrm{TEM}}$ and bla $a_{\mathrm{OXA}}$ genes co-existence was found in $10(14.49 \%)$ of patients. bla $a_{\mathrm{XXA}}, b_{\mathrm{SHV}}$ and $b / a_{\mathrm{TEM}}$ co-existence was observed in only $4(5.79 \%)$ of patients. bla $a_{\mathrm{TEM}}$ genes were detected in $55(79.71 \%)$ isolates with the highest frequency of $21(91.30 \%)$ in Klebsiella spp., isolates. bla ${ }_{\mathrm{OXA}}, b_{\mathrm{SHV}}$, and bla $\mathrm{TEM}_{\mathrm{TE}}$ co-existence was found in three Klebsiella spp., isolates but only one Proteus spp., isolates (Table-2).

\section{Validity analysis}

bla TEM $_{\text {genes were reported in } 11(20.00 \%)}$ of DDST positive isolates with $62.00 \%$ diagnostic accuracy $(95 \% \mathrm{Cl}=54.02,69.38)$ and $86.32 \%$ specificity $(77.98,91.83)$ as shown in Table-3A. These bla TEMgenes were also confirmed in $10(18.18 \%)$ CDT positive isolates with $62.67 \%$ diagnostic accuracy $(95 \% \mathrm{Cl}=54.70,70.00)$ and $88.42 \%$ specificity $(95 \% \mathrm{Cl}=80.45,93.41)$ as shown in Table-3B.

\section{Association of ESBLs genes with antimicrobial resistance}

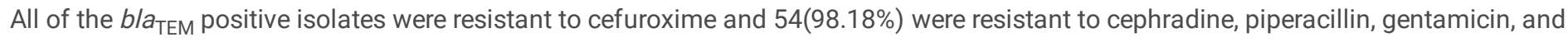

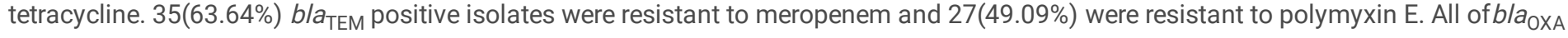
positive isolates $26(100 \%)$ were resistant to amoxicillin-clavulanate and 25(96.15\%) were resistant to cephradine, cefuroxime, doripenem, ertapenem, ciprofloxacin and tetracycline. All of the bla $\mathrm{SHV}_{\mathrm{V}}$ positive isolates $13(100 \%)$ were resistant to piperacillin and cefuroxime (Table-4).

\section{Discussion}

This study includes assessment of cephalosporins and carbapenems resistance in burns patients' clinical isolates. The frequencies of ESBLs producing bacteria also have been determined in order to find the association with antimicrobial resistance patterns. There was some small difference between the community-acquired (50.70\%) and nosocomial infections (49.30\%). Community acquired infections were less prevalent about a decade ago where only $16.90 \%$ previously infected burn patients were hospitalized (28). These findings indicate that the MDR strains are currently proliferating in the environment and the community. Self-prescription and the ease of access to the commercially available antibiotics and inappropriate prescriptions by physicians may be the contributing factors in the emergence of MDR strains $(13,18)$.Individuals with the younger age work in different factories and industries. Most of the burn victims belonged to the young age of 20-30 years in accordance with earlier research (29).

Pseudomonas spp., is the leading causative agent of burn wound infections and causes sepsis mediated mortality in 40-50\% cases (30). All of these pathogens especially Pseudomonas spp., and Klebsiella spp., are capable of adhering with and forming biofilms on inanimate objects such as catheters and surgical instruments (31). Here, the single bacterial strains were processed instead of multiple isolates for the 
antimicrobial susceptibility testing in order to determine the frequency of MDR Gram-negative pathogens. Previously multiple bacterial strains have been isolated from the burn'spatients with Pseudomonas spp., and Acinetobacter spp.,co-infection (32).

There were $83.33 \%$ (125/150) MDR isolates showing resistance against three and more classes of antimicrobial agents. These isolates were observed with more than $70 \%$ resistance against meropenem and imipenem. Early investigations on burns patients differ where more than $80 \%$ isolates were resistant to imipenem and meropenem as all of the isolates were included in the analyses (33). Molecular detection by multiplex PCR was useful as $46 \%$ of cephalosporins resistant isolates were positive for ESBLs genes. The remaining $54 \%$ resistant isolates may harbor metallo- $\beta$-lactamases (MBLs) encoding genes and other non-enzymatic resistance mechanisms. Several phenotypically negative isolates were identified by multiplex PCR as ESBLs producers. Low specificity and lack of constant sensitivity of the phenotypic tests justifies the need to use more advance molecular techniques for the rapid, specific and accurate diagnosis of ESBLs producers (34).

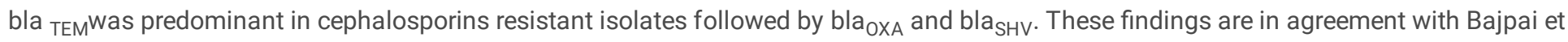
al., form New Delhi, India where bla TEM was detected in $48.70 \%$ isolates followed by bla SHV $(35)$. Shakibaieet al., reported $6.6 \%$ bla SHV $^{\text {and of }}$ $2.5 \%$ bla $_{\text {TEM }}$ from burn patients in Iran (30). The differences in the occurrence of ESBLs genes are based on their geographical distribution as

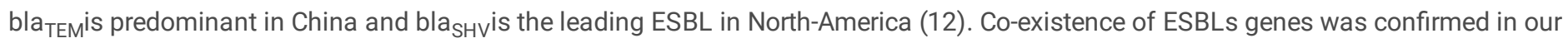
findings where bla $\mathrm{SHV}_{\mathrm{S}}$ and bla $\mathrm{T}_{\mathrm{TEM}}$ was detected in $17.39 \%$, bla $_{\mathrm{OXA}}$ and bla $\mathrm{TEM}_{\mathrm{TE}}$ in 14.49 PCR positive isolates. These findings differ from Parajuli et al., where bla $\mathrm{SHV}_{\mathrm{SH}}$ and bla $\mathrm{TEM}_{\mathrm{T}}$ co-existed in $10 \%$ isolates(5). bla $\mathrm{OXX}_{\mathrm{A}}$, bla $\mathrm{b}_{\mathrm{SHV}}$, and bla $\mathrm{TEM}_{\mathrm{TE}}$ co-existence was detected in $5.78 \%$ of isolates which indicates the parallel emergence of different ESBLs in the same isolates from burns patients and their surroundings.

The clinical presentation of patients suffering from post-burn infections is very difficult to interpret which can lead to the inappropriate prescription of antibiotics. Multi-drug resistance in burn isolates develops due to slow wound healing associated hospitalizations poor diagnosis and treatment. The incidence of post-burn infections by multi-drug resistant bacterial pathogens urgently needs to be accessed.Bacteriological and genetic profiling of ESBLs and other resistance factors provides guidance for the empiric therapy and ensures proper diagnosis. The use of multiplex PCR is very reliable and it ensures cost-effectiveness and speedy output as compared to traditional culturing and phenotypic tests. Multiplex PCR can be employed in infection control programs and to ensure higher throughput in case of outbreaks.

\section{Conclusions}

Multidrug resistant Gram-negative bacterial pathogens are responsible for the spread of antimicrobial resistance in our community and healthcare settings. Emergence of Pseudomonas spp., as the predominant pathogens followed by Enterobacteriaceae is becoming problematic in the treatment of burns patients. Phenotypic testing of ESBLs is less effective due to lower sensitivity of DDST and CDT. Molecular detection of ESBLs encoding genes by multiplex PCR is more accurate, reliable, and specific diagnostic method. bla ${ }_{\text {TEM }}$ followed

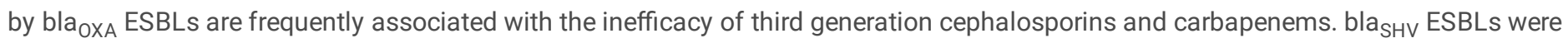
fewer in number but all of these isolated were resistant to piperacillin. It is necessary to overcome the emergence of multidrug resistant bacterial pathogens by understanding the antimicrobial resistance mechanisms other than enzymatic degradation of antibiotics. The spread of multidrug resistant strains in burn clinical settings is alarming therefore treatment strategy and infection-control management should be improved immediately.

\section{Abbreviations}

CLSI:Clinical Laboratory Standards Institute; bla $_{\mathrm{OXA}}$ :Oxacillinases; bla ${ }_{\mathrm{SHV}}$ : $\beta$-lactamase sulfhydryl variant; bla ${ }_{\mathrm{TEM}}: \beta$-lactamase TemorinaEscherichia coli mutant; ERB; Ethical Review Board; CDST:Combination disc test; DDST:Double disc synergy test; ESBL:Extendedspectrum $\beta$-Lactamase; JB\&RSC:Jinnah Burn Unit and Reconstructive Surgery Centre; MDR:Multidrug-resistant; MMG:Department of Microbiology and Molecular Genetics.

\section{Declarations Section}

\section{Ethical approval and consent to participate}

This study has been approved by the Ethical Review Board (ERB) of Allama Iqbal Medical College (AIMC) \& Jinnah Hospital Lahore in its $40^{\text {th }}$ meeting held on $12^{\text {th }}$ August, 2017.

\section{Consent for publication}


Not applicable

\section{Availability of data and materials}

The data sets analyzed during the current study are available from the corresponding author.

\section{Competing interests}

Authors declare that they have no competing interests.

\section{Funding}

No funding was received for this study.

\section{Declaration}

This work is part of Ph.D thesis of Mr. Muhammad Hayat Haider.

\section{Author's contribution}

\section{Acknowledgements}

We would like to acknowledge the Pathology Laboratory of Burn Unit and Reconstructive Surgery Centre (JB\&RSC), Jinnah Hospital Lahore for providing us the clinical isolates of burnt patients. We would also like to acknowledge Dr. Farhan Rasheed, Assistant Professor of Pathology in Allama Iqbal Medical College Lahore, for helping in demographic data collection. We are thankful to Dr. Muhammad Faisal, CEO of Citi Lab and Research Centre Lahore for providing us the guidelines to design this clinical study. This study has been partially presented in $59^{\text {th }}$ Annual International Laboratory Medicine Congress and Exhibition (LMCE) 2018, organized by Korean Society of Laboratory Medicine on November $1^{\text {st }}-3^{\text {rd }}, 2018$ in the Seoul, South Korea.

\section{Author's information}

\section{Muhammad Hayat Haider}

Ph.D Scholar

Department of Microbiology and Molecular Genetics.

University of the Punjab, Lahore

Postal address:

Country name: Pakistan

Email:

\section{Noor Ul Ain}

Ph.D Scholar

Department of Microbiology and Molecular Genetics.

University of the Punjab, Lahore

Postal address:

Country name: Pakistan

Email:

\section{Samyyia Abrar}

Ph.D Scholar 
Department of Microbiology and Molecular Genetics.

University of the Punjab, Lahore

Postal address:

Country name: Pakistan

Email:

\section{*Corresponding author}

\section{Saba Riaz}

Assistant Professor

Department of Microbiology and Molecular Genetics.

University of the Punjab, Lahore, Pakistan.

Postal address: Citilab and Research Centre, 525-A; Faisal town; Lahore

Postal code 54000.

Country name: Pakistan

Phone number: 03214530648

Email: saba.mmg@pu.edu.pk

\section{References}

1. Forjuoh SN. Burns in low-and middle-income countries: a review of available literature on descriptive epidemiology, risk factors, treatment, and prevention. Burns. 2006; 32:529-537[PubMed: 16777340]

2. Organization WH. Burns Fact sheet N 365, May 2012. In:2015.

3. Organization WH. The global burden of disease: 2004 update. 2008.

4. Rathod V, Raut S. Emergence of multi-drug resistant strains among bacterial isolates in burn wound swabs in a tertiary care centre, Nanded, Maharashtra, India. Int J Res Med Sci. 2017; 5:973-977.

5. Church D, Elsayed S, Reid O, et al. Burn wound infections. Clin Microbiol Rev. 2006; 19:403-434. [16614255]

6. Sheridan R, Weber J, Chang P, et al. Multi-drug resistant gram negative bacteria colonization and infection in burned children: Lessons learned from a 20-year experience. BurnsOpen. 2018; 2:43-46.

7. Sheridan RL. Sepsis in pediatric burn patients. Pediatr Crit Care Med.2005; 6:S112-S119.

8. Sharma L, Srivastava H, Pipal DK, et al. Bacteriological profile of burn patients and antimicrobial susceptibility pattern of burn wound isolates. Int Surg J. 2017; 4:1019-1023.

9. Richcane A, Samuel CT, Pius A, Enoch F, Thomas KG, Poku OSP. Bacteriological profile of burn wound isolates in a burns center of a tertiary hospital. J Acute Dis. 2017; 6:181.

10. Pitout JD. Infections with extended-spectrum $\beta$-lactamase-producing Enterobacteriaceae. Drugs. 2010; 70:313-333.

11. Bayram Y, Parlak M, Aypak C, et al. Three-year review of bacteriological profile and antibiogram of burn wound isolates in Van, Turkey. Int J Med Sci. 2013; 10:19. [PubMed: 23289001]

12. Ali T, Ali I, Khan NA, Han B, Gao J. The growing genetic and functional diversity of extended spectrum beta-lactamases. BioMed Res International. 2018; 26:9519718. [PubMed: 29780833]

13. Papp-Wallace KM, Endimiani A, Taracila MA, Bonomo RA. Carbapenems: past, present, and future. Antimicrob Agents Chemother. 2011; 55:4943-4960. [PubMed: 21859938]

14. Drawz SM, Bonomo RA. Three decades of $\beta$-lactamase inhibitors. Clin Microbiol Rev. 2010; 23:160-201.

15. Bush K, Jacoby GA. Updated functional classification of $\beta$-lactamases. Antimicrob Agents Chemother. 2010; 54:969-976. [PubMed: 19995920] 
16. Evans BA, Amyes SG. OXA ß-lactamases. Clin Microbiol Rev. 2014; 27:241-263. [PubMed: 24696435]

17. Ghafourian S, Sadeghifard N, Soheili S, Sekawi Z. Extended spectrum beta-lactamases: definition, classification and epidemiology. Curr Issues Mol Biol. 2014; 17:11-22. [PubMed: 24821872]

18. Shaikh S, Fatima J, Shakil S, Rizvi SMD, Kamal MA. Antibiotic resistance and extended spectrum beta-lactamases: Types, epidemiology and treatment. Saudi J Biol Sci. 2015; 22:90-101.

19. Hussain M, Munir S, Fatima M, et al. Antimicrobial susceptibility patterns and CTX-M $\beta$-lactamase producing clinical isolates from burn patients in Islamabad, Pakistan. Asian Pac J Trop Dis. 2017; 7:486-490.

20. Ali T, Zhang L, Shahid M, et al. ESBL-producing Escherichiacoli from cows suffering mastitis in China contain clinical class 1 integrons with CTX-M linked to ISCR1. Front Microb. 2016; 7:1931. [PubMed: 27965653]

21. Rather IA, Kim B-C, Bajpai VK, Park Y-H. Self-medication and antibiotic resistance: Crisis, current challenges, and prevention. Saudi J Biol Sci. 2017;24:808-812. [PubMed: 28490950]

22. Cohen Stuart J, Dierikx C, Al Naiemi N, et al. Rapid detection of TEM, SHV and CTX-M extended-spectrum $\beta$-lactamases in Enterobacteriaceae using ligation-mediated amplification with microarray analysis. J Antimicrob Chemother. 2010; 65:1377-1381. [PubMed: 20462947]

23. Wayne P. Clinical and laboratory standards institute. Performance standards for antimicrobial susceptibility testing. 2017.

24. Ibrahim Y, Sani Y, Saleh Q, Saleh A, Hakeem G. Phenotypic detection of extended spectrum beta lactamase and carbapenemase coproducing clinical isolates from two tertiary hospitals in Kano, North West Nigeria. Ethiop J Health Sci. 2017; 27:3-10. [PubMed: 28458485]

25. Babu L, Reddy P, Murali HS, Batra HV. Optimization and evaluation of a multiplex PCR for simultaneous detection of prominent foodborne pathogens of Enterobacteriaceae. Ann Microbiol. 2013; 63:1591-1599.

26. Colom K, Pérez J, Alonso R, Fernández-Aranguiz A, Lariño E, Cisterna R. Simple and reliable multiplex PCR assay for detection of bla TEM, bla SHV and bla OXA-1 genes in Enterobacteriaceae. FEMS Microbiol Lett. 2003; 223:147-151. [PubMed: 12829279]

27. Mabilat C, Courvalin P. Development of" oligotyping" for characterization and molecular epidemiology of TEM beta-lactamases in members of the family Enterobacteriaceae. Antimicrob Agents Chemother. 1990; 34:2210-2216. [PubMed: 2073111]

28. Taneja N, Emmanuel R, Chari P, Sharma M. A prospective study of hospital-acquired infections in burn patients at a tertiary care referral centre in North India. Burns. 2004; 30:665-669. [PubMed: 15475139]

29. Azimi L, Motevallian A, Ebrahimzadeh Namvar A, Asghari B, Lari AR. Nosocomial infections in burned patients in motahari hospital, tehran, iran. Dermatol Res Pract. 2011; 2011:436952. [PubMed: 22203838]

30. Shakibaie MR, Shahcheraghi F, Hashemi A, Adeli NS. Detection of TEM, SHV and PER Type Extended-Spectrum ß-Lactamase Genes among Clinical Strains of Pseudomonasaeruginosa Isolated from Burnt Patients at Shafa-Hospital, Kerman, Iran. Iranian J Basic Med Sci. 2008; 11:104-111.

31. Singh S, Singh SK, Chowdhury I, Singh R. Understanding the mechanism of bacterial biofilms resistance to antimicrobial agents. Open Microbiol J. 2017; 11:53. [PubMed: 28553416]

32. Leseva M, Arguirova M, Nashev D, Zamfirova E, Hadzhyiski O. Nosocomial infections in burn patients: etiology, antimicrobial resistance, means to control. Ann Burns Fire Disast. 2013; 26:5.

33. Berendonk TU, Manaia CM, Merlin C, et al. Tackling antibiotic resistance: the environmental framework. Nat Rev Microbiol. 2015; 13:310. [PubMed: 25817583]

34. Krishnamurthy V, Vijaykumar G, Kumar S, Prashanth H, Prakash R, Nagaraj E. Phenotypic and genotypic methods for detection of extended spectrum $\beta$ lactamase producing Escherichiacoli and Klebsiellapneumoniae isolated from ventilator associated pneumonia. J Clin Diagnost Res: JCDR. 2013; 7:1975. [PubMed: 24179913]

35. Bajpai T, Pandey M, Varma M, Bhatambare G. Prevalence of TEM, SHV, and CTX-M Beta-Lactamase genes in the urinary isolates of a tertiary care hospital. Avicenna J Med. 2017; 7:12.

\section{Tables}

Table-1: Antimicrobial sensitivity and resistance patterns of clinical isolates from burnt patients. 


\begin{tabular}{|c|c|c|c|}
\hline \multirow[t]{2}{*}{ Antibiotics } & \multicolumn{3}{|c|}{ Antimicrobial susceptibility patterns of isolates } \\
\hline & $\begin{array}{c}\text { Sensitive (S) } \\
\text { n (\%) }\end{array}$ & $\begin{array}{c}\text { Intermediate (I) } \\
\mathrm{n}(\%)\end{array}$ & $\begin{array}{c}\text { Resistant (R) } \\
\mathrm{n}(\%)\end{array}$ \\
\hline \multicolumn{4}{|c|}{ Penicillins / $\beta$-lactamase inhibitors } \\
\hline Piperacillin (PIP) & $7(4.70 \%)$ & $2(1.30 \%)$ & $141(94.00 \%)$ \\
\hline Amoxycillin-clavulanate (AMC) & $8(5.30 \%)$ & $2(1.30 \%)$ & $140(93.30 \%)$ \\
\hline Ampicillin-sulbactam (SAM) & $13(8.70 \%)$ & $6(4.00 \%)$ & $131(87.30 \%)$ \\
\hline Piperacillin-tazobactam (TZP) & $26(17.30 \%)$ & $14(9.30 \%)$ & $110(73.30 \%)$ \\
\hline \multicolumn{4}{|c|}{ Cephalosporins / $\beta$-lactamase inhibitors } \\
\hline Ceftazidime (CAZ) & $14(9.30 \%)$ & $14(9.30 \%)$ & $122(81.30 \%)$ \\
\hline Cephradine (CE) & $2(1.30 \%)$ & $1(0.70 \%)$ & $147(98.00 \%)$ \\
\hline Cefoperazone (CFP) & $22(14.70 \%)$ & $5(3.30 \%)$ & $123(82.00 \%)$ \\
\hline Cefoperazone-sulbactam (SCF) & $38(25.30 \%)$ & $10(6.70 \%)$ & $102(68.00 \%)$ \\
\hline Cefotaxime (CTX) & $14(9.30 \%)$ & $5(3.30 \%)$ & $131(87.30 \%)$ \\
\hline Ceftriaxone (CRO) & $12(8.00 \%)$ & $6(4.00 \%)$ & $132(88.00 \%)$ \\
\hline Cefuroxime (CXM) & $2(1.30 \%)$ & $2(1.30 \%)$ & $146(97.30 \%)$ \\
\hline \multicolumn{4}{|l|}{ Carbapenems } \\
\hline Doripenem (DOR) & $17(11.30 \%)$ & - & $133(88.70 \%)$ \\
\hline Ertapenem (ETP) & $5(3.30 \%)$ & - & $145(96.70 \%)$ \\
\hline Imipenem (IMI) & $38(25.30 \%)$ & $9(6.00 \%)$ & $103(68.70 \%)$ \\
\hline Meropenem (MEM) & $43(28.70 \%)$ & $2(1.30 \%)$ & $105(70.00 \%)$ \\
\hline \multicolumn{4}{|l|}{ Aminoglycosides } \\
\hline Amikacin (AK) & $39(26 \%)$ & $7(4.70 \%)$ & $104(69.30 \%)$ \\
\hline Gentamicin (GEN) & $8(5.30 \%)$ & - & $142(94.70 \%)$ \\
\hline Tobramycin (TOB) & $7(4.70 \%)$ & - & $143(95.30 \%)$ \\
\hline \multicolumn{4}{|l|}{ Quinolones / Fluoroquinolones } \\
\hline Nalidixic acid (NAL) & $6(4.00 \%)$ & - & $144(96.00 \%)$ \\
\hline Ciprofloxacin (CIP) & $11(7.30 \%)$ & - & $139(92.70 \%)$ \\
\hline Levofloxacin (LEV) & $18(12.00 \%)$ & $3(2.00 \%)$ & $129(86.00 \%)$ \\
\hline Ofloxacin (OFL) & $5(3.30 \%)$ & $3(2.00 \%)$ & $142(94.70 \%)$ \\
\hline \multicolumn{4}{|l|}{ Others } \\
\hline Aztreonam (ATM) & $13(8.70 \%)$ & $36(24.00 \%)$ & $101(67.30 \%)$ \\
\hline Tigecycline (TGC) & $17(11.30 \%)$ & $21(14.00 \%)$ & $112(74.70 \%)$ \\
\hline Tetracycline (TET) & $4(2.70 \%)$ & - & $146(97.30 \%)$ \\
\hline Polymyxin E (PE) & $83(55.30 \%)$ & - & $67(44.70 \%)$ \\
\hline
\end{tabular}

Table-2: ESBLs genotypes found to be disseminated among PCR positive clinical isolates.

\begin{tabular}{|c|c|c|c|c|c|c|c|}
\hline \multirow[t]{2}{*}{ PCR positive isolates } & \multicolumn{7}{|c|}{ ESBLs genotypes } \\
\hline & $\begin{array}{c}\text { blaOXA } \\
\text { n (\%) }\end{array}$ & $\begin{array}{c}\text { blasHV } \\
\text { n (\%) }\end{array}$ & $\begin{array}{c}\text { blaTEM } \\
\text { n (\%) }\end{array}$ & $\begin{array}{c}\text { bla OXA-bla }_{\text {SHV }} \\
\text { n (\%) }\end{array}$ & $\begin{array}{c}\text { bla }_{\text {SHV }}-b_{\text {bla }} \\
\text { n (\%) }\end{array}$ & $\begin{array}{c}\text { bla OXA-bla }_{\text {TEM }} \\
\text { n (\%) }\end{array}$ & $\begin{array}{c}\text { blaOXA }^{-b l a} \text { SHV }-b l a_{\text {TEM }} \\
\text { n (\%) }\end{array}$ \\
\hline $\begin{array}{c}\text { Pseudomonas spp., } \\
29(42.03 \%)\end{array}$ & $14(48.28 \%)$ & $2(6.89 \%)$ & $18(62.07 \%)$ & - & $\begin{array}{c}2 \\
(6.89 \%)\end{array}$ & $\begin{array}{c}3 \\
(10.34 \%)\end{array}$ & - \\
\hline $\begin{array}{l}\text { Klebsiella spp., } \\
23(33.33 \%)\end{array}$ & $6(26.09 \%)$ & $9(39.13 \%)$ & $21(91.30 \%)$ & $\begin{array}{c}3 \\
(13.04 \%) \\
\end{array}$ & $\begin{array}{c}8 \\
(34.78 \%) \\
\end{array}$ & $\begin{array}{c}2 \\
(8.69 \%)\end{array}$ & $\begin{array}{c}3 \\
(13.04 \%) \\
\end{array}$ \\
\hline $\begin{array}{c}\text { Acinetobacter spp., } \\
13(18.84 \%) \\
\end{array}$ & $4(30.77 \%)$ & $1(7.69 \%)$ & $12(92.31 \%)$ & - & $\begin{array}{c}1 \\
(7.69 \%) \\
\end{array}$ & $\begin{array}{c}5 \\
(38.46 \%) \\
\end{array}$ & - \\
\hline $\begin{array}{c}\text { Proteus spp., } \\
4(5.78 \%) \\
\end{array}$ & $2(50.00 \%)$ & $1(25.00 \%)$ & $\begin{array}{c}4 \\
(100 \%)\end{array}$ & $\begin{array}{c}1 \\
(25.00 \%) \\
\end{array}$ & $\begin{array}{c}1 \\
(25.00 \%) \\
\end{array}$ & - & $\begin{array}{c}1 \\
(25.00 \%) \\
\end{array}$ \\
\hline $\begin{array}{l}\text { Total } \\
(\mathrm{n}=69)\end{array}$ & 26 (37.68\%) & 13 (18.84\%) & $55(79.71 \%)$ & $\begin{array}{c}4 \\
(5.78 \%) \\
\end{array}$ & $12(17.39 \%)$ & $\begin{array}{c}10 \\
(14.49 \%) \\
\end{array}$ & $\begin{array}{c}4 \\
(5.78 \%) \\
\end{array}$ \\
\hline
\end{tabular}

Table-3: Validity testing of ESBLs detection by phenotypic testing and molecular detection by multiplex PCR. 


\begin{tabular}{|c|c|c|c|c|c|c|c|c|c|c|c|}
\hline Multiplex PCR & $\begin{array}{c}\text { DDST } \\
\text { Positive } \\
\text { n (\%) }\end{array}$ & $\begin{array}{l}\text { DDST Not- } \\
\text { determined } \\
\mathbf{n}(\%)\end{array}$ & $\begin{array}{c}\text { DDST } \\
\text { Sensitivity } \\
\text { (\%), } \\
95 \% \text { CI }\end{array}$ & $\begin{array}{c}\text { DDST } \\
\text { Specificity } \\
(\%), \\
95 \% \text { CI }\end{array}$ & $\begin{array}{c}\text { DDST } \\
\text { Diagnostic } \\
\text { Accuracy } \\
(\%), \\
95 \% \text { CI }\end{array}$ & $\begin{array}{c}\text { Positive } \\
\text { DDST } \\
\text { Predictive } \\
\text { Value } \\
\text { (\%), } \\
95 \% \text { CI }\end{array}$ & $\begin{array}{c}\text { Negative } \\
\text { DDST } \\
\text { Predictive } \\
\text { Value } \\
\text { (\%), } \\
95 \% \text { CI }\end{array}$ & $\begin{array}{c}\text { Positive } \\
\text { DDST } \\
\text { Likelihood } \\
\text { Ratio, } \\
\text { 95\% CI }\end{array}$ & $\begin{array}{c}\text { Negative } \\
\text { DDST } \\
\text { Likelihood } \\
\text { Ratio, } \\
95 \% \text { CI }\end{array}$ & $x^{2}$ & $\begin{array}{c}\mathrm{p}- \\
\text { value }\end{array}$ \\
\hline blaOXA Positive & $\begin{array}{c}3 \\
(13.04 \%) \\
\end{array}$ & $\begin{array}{c}23 \\
(88.46 \%) \\
\end{array}$ & \multirow{2}{*}{$\begin{array}{l}11.54 \% \\
(4.003, \\
28.98)\end{array}$} & \multirow{2}{*}{$\begin{array}{l}83.06 \% \\
(75.49, \\
88.65)\end{array}$} & \multirow{2}{*}{$\begin{array}{l}70.67 \% \\
(62.94 \\
77.36)\end{array}$} & \multirow{2}{*}{$\begin{array}{c}12.50 \% \\
(4.344 \\
31)\end{array}$} & \multirow{2}{*}{$\begin{array}{c}81.75 \% \\
(74.1 \\
87.52)\end{array}$} & \multirow{2}{*}{$\begin{array}{c}0.6813 \\
(0.004145 \\
-112)\end{array}$} & \multirow{2}{*}{$\begin{array}{c}1.065 \\
(0.9742- \\
1.164)\end{array}$} & \multirow[t]{2}{*}{0.466} & \multirow[t]{2}{*}{0.769} \\
\hline blaOXANegative & $\begin{array}{c}21 \\
(16.94 \%)\end{array}$ & $\begin{array}{c}103 \\
(83.06 \%)\end{array}$ & & & & & & & & & \\
\hline blashvPositive & $\begin{array}{c}3 \\
(23.07 \%)\end{array}$ & $\begin{array}{c}10 \\
(76.92 \%)\end{array}$ & \multirow{2}{*}{$\begin{array}{l}23.08 \% \\
(8.179 \\
50.26)\end{array}$} & \multirow{2}{*}{$\begin{array}{c}84.67 \% \\
(77.7 \\
89.75)\end{array}$} & \multirow{2}{*}{$\begin{array}{l}79.33 \% \\
(72.16, \\
85.04)\end{array}$} & \multirow{2}{*}{$\begin{array}{c}12.50 \% \\
(4.344 \\
31)\end{array}$} & \multirow{2}{*}{$\begin{array}{l}92.06 \% \\
(86.01 \\
95.63)\end{array}$} & \multirow{2}{*}{$\begin{array}{c}1.505 \\
(0.1554- \\
14.59)\end{array}$} & \multirow{2}{*}{$\begin{array}{c}0.9085 \\
(0.7445- \\
1.109)\end{array}$} & \multirow[t]{2}{*}{0.530} & \multirow[t]{2}{*}{0.438} \\
\hline blasHVNegative & $\begin{array}{c}21 \\
(15.32 \%) \\
\end{array}$ & $\begin{array}{c}116 \\
(84.67 \%) \\
\end{array}$ & & & & & & & & & \\
\hline blaTEMPositive & $\begin{array}{c}11 \\
(20 \%) \\
\end{array}$ & $\begin{array}{c}44 \\
(80 \%) \\
\end{array}$ & \multirow{2}{*}{$\begin{array}{c}20 \% \\
(11.55, \\
32.37)\end{array}$} & \multirow{2}{*}{$\begin{array}{l}86.32 \% \\
(77.98, \\
91.83)\end{array}$} & \multirow{2}{*}{$\begin{array}{c}62 \% \\
(54.02, \\
69.38)\end{array}$} & \multirow{2}{*}{$\begin{array}{l}45.83 \% \\
(27.89, \\
64.93)\end{array}$} & \multirow{2}{*}{$\begin{array}{l}65.08 \% \\
(56.42, \\
72.85)\end{array}$} & \multirow{2}{*}{$\begin{array}{c}1.462 \\
(0.6163- \\
3.466)\end{array}$} & \multirow{2}{*}{$\begin{array}{c}0.9268 \\
(0.8831- \\
0.9727)\end{array}$} & \multirow[t]{2}{*}{1.034} & \multirow[t]{2}{*}{0.309} \\
\hline bla TEMNegative & $\begin{array}{c}13 \\
(13.68 \%)\end{array}$ & $\begin{array}{c}82 \\
(86.34 \%)\end{array}$ & & & & & & & & & \\
\hline \multicolumn{12}{|c|}{ Table-3B: Validity analysis of ESBLs detection by CDT as compared to multiplex PCR. } \\
\hline Multiplex PCR & $\begin{array}{c}\text { CDT } \\
\text { Positive } \\
\text { n (\%) }\end{array}$ & $\begin{array}{c}\text { CDT Not- } \\
\text { determined } \\
\mathrm{n}(\%)\end{array}$ & $\begin{array}{c}\text { CDT } \\
\text { Sensitivity } \\
\text { (\%), } \\
95 \% \text { CI }\end{array}$ & $\begin{array}{c}\text { CDT } \\
\text { Specificity } \\
(\%), \\
95 \% \text { CI }\end{array}$ & $\begin{array}{c}\text { CDT } \\
\text { Diagnostic } \\
\text { Accuracy } \\
(\%), \\
95 \% \text { CI }\end{array}$ & $\begin{array}{c}\text { Positive } \\
\text { CDT } \\
\text { Predictive } \\
\text { Value } \\
\text { (\%), } \\
95 \% \text { CI }\end{array}$ & $\begin{array}{c}\text { Negative } \\
\text { CDT } \\
\text { Predictive } \\
\text { Value } \\
\text { (\%), } \\
95 \% \text { CI }\end{array}$ & $\begin{array}{c}\text { Positive } \\
\text { CDT } \\
\text { Likelihood } \\
\text { Ratio, } \\
95 \% \text { CI }\end{array}$ & $\begin{array}{c}\text { Negative } \\
\text { CDT } \\
\text { Likelihood } \\
\text { Ratio, } \\
95 \% \text { CI }\end{array}$ & $x^{2}$ & $\begin{array}{c}\mathrm{p}- \\
\text { value }\end{array}$ \\
\hline blaOXA Positive & $\begin{array}{c}5 \\
(19.23 \%) \\
\end{array}$ & $\begin{array}{c}21 \\
(80.77 \%)\end{array}$ & \multirow{2}{*}{$\begin{array}{l}19.23 \% \\
(8.507 \\
37.88)\end{array}$} & \multirow{2}{*}{$\begin{array}{c}87.10 \% \\
(80.06, \\
91.9)\end{array}$} & \multirow{2}{*}{$\begin{array}{l}75.33 \% \\
(67.86, \\
81.54)\end{array}$} & \multirow{2}{*}{$\begin{array}{l}23.81 \% \\
(10.63, \\
45.09)\end{array}$} & \multirow{2}{*}{$\begin{array}{c}83.72 \% \\
(76.39 \\
89.1)\end{array}$} & \multirow{2}{*}{$\begin{array}{c}1.49 \\
(0.2541- \\
8.74)\end{array}$} & \multirow{2}{*}{$\begin{array}{c}0.9274 \\
(0.8424- \\
1.021)\end{array}$} & \multirow[t]{2}{*}{0.715} & 0.368 \\
\hline blaOXANegative & $\begin{array}{c}16 \\
(12.90 \%) \\
\end{array}$ & $\begin{array}{c}108 \\
(87.09 \%) \\
\end{array}$ & & & & & & & & & \\
\hline blasHVPositive & $\begin{array}{c}2 \\
(15.38 \%) \\
\end{array}$ & $\begin{array}{c}11 \\
(84.62 \%) \\
\end{array}$ & $\begin{array}{l}15.38 \% \\
\text { (4.326, }\end{array}$ & $\begin{array}{l}86.13 \% \\
\text { (79.35, }\end{array}$ & $\begin{array}{c}80 \% \\
(72.89,\end{array}$ & $\begin{array}{l}9.524 \% \\
(2.652\end{array}$ & $\begin{array}{l}91.47 \% \\
\text { (85.38, }\end{array}$ & $\begin{array}{c}1.109 \\
(0.004565\end{array}$ & $\begin{array}{c}0.9824 \\
(0.8199-\end{array}$ & 0.023 & 1.000 \\
\hline blasHVNegative & $\begin{array}{c}19 \\
(13.87 \%)\end{array}$ & $\begin{array}{c}118 \\
(86.13 \%)\end{array}$ & 42.24) & 90.94) & 85.62) & 28.91) & 95.17) & - 269.6) & 1.177) & & \\
\hline blaTEMPositive & $\begin{array}{c}10 \\
(18.18 \%) \\
\end{array}$ & $\begin{array}{c}45 \\
(81.82 \%) \\
\end{array}$ & $\begin{array}{l}18.18 \% \\
(10.19\end{array}$ & $\begin{array}{l}88.42 \% \\
(80.45\end{array}$ & $\begin{array}{c}62.67 \% \\
(54.7,70)\end{array}$ & $\begin{array}{l}47.62 \% \\
\text { (28.34 }\end{array}$ & $\begin{array}{l}65.12 \% \\
(56.56\end{array}$ & $\begin{array}{c}1.57 \\
(0.5439-\end{array}$ & $\begin{array}{c}0.9253 \\
(0.8832-\end{array}$ & 1.261 & 0.261 \\
\hline blaTEMNegative & $\begin{array}{c}11 \\
(11.58 \%)\end{array}$ & $\begin{array}{c}84 \\
(88.42 \%) \\
\end{array}$ & 30.33) & 93.41) & & 67.63) & 72.8) & 4.533) & 0.9695) & & \\
\hline
\end{tabular}

Table-4: Association of ESBLs genes with the antimicrobial susceptibility patterns of clinical isolates. 


\begin{tabular}{|c|c|c|c|c|c|c|c|c|c|}
\hline \multirow[t]{2}{*}{ Antibiotics } & \multicolumn{9}{|c|}{$\begin{array}{c}\text { ESBLs genes detected by multiplex PCR } \\
n / 150(\%)\end{array}$} \\
\hline & \multicolumn{3}{|c|}{$\begin{array}{c}\text { blaOXA } \\
26 / 150(17.30 \%)\end{array}$} & \multicolumn{3}{|c|}{$\begin{array}{c}\text { blaSHV } \\
13 / 150(8.67 \%)\end{array}$} & \multicolumn{3}{|c|}{$\begin{array}{c}\text { bla TEM } \\
55 / 150(36.67 \%)\end{array}$} \\
\hline PIP & $3(11.54 \%)$ & - & $23(88.46 \%)$ & - & - & $13(100 \%)$ & - & $1(1.82 \%)$ & $54(98.18 \%)$ \\
\hline $\mathrm{AMC}$ & - & - & $26(100 \%)$ & $1(7.69 \%)$ & - & $12(92.31 \%)$ & $4(7.27 \%)$ & - & $51(92.73 \%)$ \\
\hline TZP & $5(19.23 \%)$ & $3(11.54 \%)$ & $18(69.23 \%)$ & $2(15.38 \%)$ & $3(23.08 \%)$ & $8(61.54 \%)$ & $11(20.00 \%)$ & $6(10.91 \%)$ & $38(69.09 \%)$ \\
\hline CAZ & $1(3.85 \%)$ & $4(15.38 \%)$ & $21(80.77 \%)$ & $1(7.69 \%)$ & $1(7.69 \%)$ & $11(84.62 \%)$ & $2(3.64 \%)$ & $6(10.91 \%)$ & $47(85.45 \%)$ \\
\hline $\mathrm{CE}$ & - & $1(3.85 \%)$ & 25 (96.15\%) & - & $1(7.69 \%)$ & $12(92.31 \%)$ & - & $1(1.82 \%)$ & $54(98.18 \%)$ \\
\hline CFP & $3(11.54 \%)$ & - & $23(88.46 \%)$ & $3(23.08 \%)$ & - & $10(76.92 \%)$ & $5(9.09 \%)$ & $3(5.45 \%)$ & $47(85.45 \%)$ \\
\hline SCF & $6(23.08 \%)$ & $4(15.38 \%)$ & $16(61.54 \%)$ & $3(23.08 \%)$ & $2(15.38 \%)$ & $8(61.54 \%)$ & $15(27.27 \%)$ & $6(10.91 \%)$ & $34(61.82 \%)$ \\
\hline CTX & $3(11.54 \%)$ & $1(3.85 \%)$ & $22(84.62 \%)$ & - & $1(7.69 \%)$ & $12(92.31 \%)$ & $3(5.45 \%)$ & $3(5.45 \%)$ & 49 (89.09\%) \\
\hline ETP & $1(3.85 \%)$ & - & $25(96.15 \%)$ & $1(7.69 \%)$ & - & $12(92.31 \%)$ & $2(3.64 \%)$ & - & $53(96.36 \%)$ \\
\hline IMI & $7(26.92 \%)$ & $1(3.85 \%)$ & $18(69.23 \%)$ & $4(30.77 \%)$ & $1(7.69 \%)$ & $8(61.54 \%)$ & 17 (30.91\%) & $4(7.27 \%)$ & $34(61.82 \%)$ \\
\hline MEM & $9(34.62 \%)$ & - & 17 (65.38\%) & $5(38.46 \%)$ & - & $8(61.54 \%)$ & $20(36.36 \%)$ & - & 35 (63.64\%) \\
\hline $\mathrm{AK}$ & $6(23.08 \%)$ & $2(7.69 \%)$ & $18(69.23 \%)$ & $4(30.77 \%)$ & - & $9(69.23 \%)$ & $17(30.91 \%)$ & $1(1.82 \%)$ & $37(67.27 \%)$ \\
\hline GEN & $2(7.69 \%)$ & - & $24(92.31 \%)$ & $1(7.69 \%)$ & - & $12(92.31 \%)$ & $1(1.82 \%)$ & - & $54(98.18 \%)$ \\
\hline TOB & $2(7.69 \%)$ & - & $24(92.31 \%)$ & - & - & $13(100 \%)$ & $2(3.64 \%)$ & - & $53(96.36 \%)$ \\
\hline NAL & $2(7.69 \%)$ & - & $24(92.31 \%)$ & $1(7.69 \%)$ & - & 12 (92.31\%) & $4(7.27 \%)$ & - & 51 (92.73\%) \\
\hline CIP & $1(3.85 \%)$ & - & $25(96.15 \%)$ & $1(7.69 \%)$ & - & $12(92.31 \%)$ & $3(5.45 \%)$ & - & $52(94.55 \%)$ \\
\hline LEV & $3(11.54 \%)$ & - & $23(88.46 \%)$ & $1(7.69 \%)$ & - & 12 (92.31\%) & $8(14.55 \%)$ & $1(1.82 \%)$ & 46 (83.64\%) \\
\hline OFL & $1(3.85 \%)$ & $1(3.85 \%)$ & $24(92.31 \%)$ & $1(7.69 \%)$ & $1(7.69 \%)$ & $11(84.62 \%)$ & $1(1.82 \%)$ & $1(1.82 \%)$ & 53 (96.36\%) \\
\hline ATM & $1(3.85 \%)$ & 11 & 14 (53.85\%) & - & $4(7.27 \%)$ & 9 (69.23\%) & $1(1.82 \%)$ & $11(20.00 \%)$ & 43 (78.18\%) \\
\hline
\end{tabular}

